"Przegląd Prawa Konstytucyjnego" Nr $4(16) / 2013$

\title{
Sprawozdanie
}

\section{Europejski Kongres Praw Człowieka, Katowice, 6 grudnia 2012 r.}

W dniu 6 grudnia 2012 r. na Wydziale Prawa i Administracji Uniwersytetu Śląskiego w Katowicach odbył się III Europejski Kongres Praw Człowieka, którego tematem były procesy demokratyzacji w Europie Wschodniej. Kongres to wydarzenie organizowane przez biuro dr. Marka Migalskiego oraz stowarzyszenie Projekt Śląsk we współpracy z m.in. Grupą Europejskich Konserwatystów i Reformatorów, Korespondentem Wschodnim oraz Kołem Naukowym Prawa Konstytucyjnego WPiA UŚ.

Organizatorom udało się zaprosić szereg osobistości, które z tematyką konferencji spotykają się zarówno w swojej działalności politycznej, jak i społecznej czy też akademickiej.

Plan spotkania obejmował trzy panele, z których każdy dotyczył przemian zachodzących w jednym z państw Wschodu - Białorusi, Rosji i Ukrainy.

Pierwszy z paneli starał się odpowiedzieć na pytanie o rolę nowych mediów w procesach demokratyzacji na Białorusi. Udział wzięli w nim Stanisław Szuszkiewicz (pierwszy prezydent niepodległej Białorusi), Natalia Radzina (redaktor naczelna portalu Karta 97), Wiaczesław Dianow (organizator tzw. „milczących protestów”), Franak Wiaczorka (opozycyjny działacz młodzieżowy, współpracownik Radia Wolna Europa i Radia Swaboda) oraz Dzmitrij Novikau (prezes Europejskiego Radia dla Białorusi).

Uczestnicy zgadzali się co do tego, że nowe media niosą za sobą pozytywne zmiany. Całodobowe nadawanie kanału telewizyjnego z Polski, wsparcie kanałów europejskich, Internet, rozwijanie prasy podziemnej - czynniki te przyczyniają się do zmian w świadomości społecznej. Dzięki nim jest także możliwy dostęp do niezależnej od władzy informacji. Stwarza to pole do 
rozwoju rzetelnego dziennikarstwa. Wszystko to przyczynia się do powrotu Białorusi do demokracji.

Drugi panel został zatytułowany „Ruch protestacyjny - szansa na demokratyzację w Rosji?”. Głos zabrali dr Wiktor Ross (politolog, były ambasador Polski w Rosji i Mołdawii), Andrzej Brzeziecki (redaktor naczelny „Nowej Europy Wschodniej”) oraz Katarzyna Jarzyńska (ekspert Ośrodka Studiów Wschodnich). Debatę prowadził redaktor Marek Magierowski, który na wstępie zauważył, iż wizerunek opozycji demokratycznej w Rosji obciąża pamięć o kryzysowych czasach lat 90. ubiegłego wieku. Był to okres, który wielu Rosjan postrzega jako czas rozkradania państwa, pomimo iż równocześnie wielu emerytów nie dostawało regularnie emerytur. Wielu dzisiejszych opozycjonistów zaliczało się wówczas do ścisłego kręgu władzy. Prowadzący postawił więc pytanie, czy ma to wpływ na fakt, że obecnej opozycji tak trudno przekonać do siebie Rosjan.

K. Jarzyńska zauważyła, iż społeczeństwo istotnie nie ufa tym liderom, co miało swoje przełożenie na brak protestów w wyborczym 2011 r. Obecnie społeczeństwo rosyjskie czeka na nowych przywódców, którzy podejmą realne wyzwania dnia dzisiejszego, a nie będą jedynie nawoływać do wprawdzie szczytnych, ale jednak dla wielu przeciętnych Rosjan pustych haseł demokracji. Na to nakłada się także fakt, iż opozycja jest mocno wewnętrznie podzielona.

Zdaniem A. Brzezickiego mówienie o „opozycji demokratycznej” w Rosji jest mylące, bo pod tym pojęciem rozumie się zarówno liberałów, jak i nacjonalistów oraz komunistów. Współcześnie w Rosji mamy do czynienia raczej z opozycją antyputinowską, którą trudno określić nawet jako opozycję antysystemową.

W. Ross zwrócił uwagę, iż w latach 90. w Rosji dokonał się ogromny przełom, polegający na przejściu do swoiście rozumianego „wolnego rynku”. Ówczesna prywatyzacja dla wielu miała charakter kradzieży, ponieważ ogromny majątek państwowy w zasadzie za darmo dostał się w ręce nielicznej grupy. Z tego względu nowo powstała klasa średnia była bardzo słaba. Stąd pojawiło się pragnienie posiadania silnej władzy, która ochroni jej przedstawicieli. W rzeczywistości W. Putin okazał się jednak przedstawicielem interesów oligarchów - M. Chodorkowski został osadzony, ponieważ „miał czelność” wskazać, iż dalsza taka polityka, polityka ochrony oligar- 
chicznego systemu, nie doprowadzi Rosji do rozkwitu. W ocenie byłego ambasadora jedynym w istocie sukcesem obecnego prezydenta Rosji jest to, że wykorzystał zwyżkę cen surowców, co umożliwiło Rosji w miarę bezbolesne przejście przez kryzys. Dzięki temu Putin cieszył się jeszcze do niedawna $80 \%$ poparciem - w tym kontekście należy więc uznać za sukces, iż na ulice Moskwy wychodzą grupy 100000 obywateli w ramach protestu. Opozycja jednak nie potrafi wykorzystać tej koniunktury, nie mogąc wspólnie ustalić nawet pierwszego kroku, co grozi ryzykiem powtórzenia polskiego syndromu „konwentu św. Katarzyny”. Część opozycji stoi bowiem na stanowisku, iż Putina nie da się usunąć, a więc należy przynajmniej żądać drobnych ustępstw ze strony władzy. Z kolei druga część jest znacznie bardziej radykalna. Tak więc obecna opozycja to zgromadzenie ludzi o bardzo różnych poglądach.

W kolejnej części prelegenci zwrócili uwagę, że w ramach opozycji może wyrosnąć nowe zagrożenie. Zdaniem K. Jarzyńskiej duży potencjał mają bowiem hasła nacjonalistyczne (powstałe na kanwie znacznej nielegalnej emigracji), co może stanowić swoistą bombę z opóźnionym zapłonem - odwoływanie się do takich tendencji może w przyszłości zrodzić duże problemy. A. Brzezicki zwrócił uwagę, iż na to nakłada się także problem demograficzny - samych Rosjan jest coraz mniej. Rosja potrzebuje jednak ok. 5 mln rąk do pracy, dlatego państwo zezwala na imigrację z Kaukazu, co rodzi konflikty społeczne. Napięcie będzie więc tylko postępować.

Kolejne pytanie dotyczyło określenia, czym jest demokracja dla Rosjan. M. Magierowski zauważył, iż ruch opozycyjny twierdzi, że obecny system nie jest demokratyczny, na co W. Putin odpowiada, że system liberalnego demokratyzmu Zachodu także nie jest doskonały. W odpowiedzi A. Brzezicki stwierdził, iż dla Rosjan „demokracja” jest pojęciem mocno abstrakcyjnym, nie mają bowiem z demokracją doświadczenia. Niemniej dla wielu nie jest to system idealny - takiego upatrują w Chinach, gdzie współistnieją solidne rządy oraz bogata gospodarka.

Ostatni temat panelu dotyczył pytania „Co po Putinie?”. Wszystko zależy od nastrojów społecznych - wskazał A. Brzezicki - od tego, czy ludzie będą chcieli spokoju społecznego, walki z korupcją czy też może czegoś innego. Obecna sytuacja jest mocno skomplikowana, trudno więc cokolwiek przewidzieć. Dla K. Jarzyńskiej niekoniecznie musi dojść do czasu „po Putinie”. 
Ostatnie protesty w Rosji były mobilizacją tej części społeczeństwa, która jest apolityczna w tym sensie, że nie chodzi im o rewolucję, zmianę władzy, lecz o to, by władza zaczęła się liczyć z prawami ludzi. To odniosło skutek - plany wprowadzenia antydemokratycznych rozwiązań (np. ustawy ograniczającej prawo do zgromadzeń) trafiły do kosza. Trzeba jednak pamiętać, że Rosja to ogromny kraj, gdzie problemy miast są inne niż problemy prowincji. Ta druga domaga się bowiem większej obecności państwa, a co za tym idzie, większej liczby rozwiązań socjalnych.

Panel zakończył M. Magierowski stwierdzeniem, iż należy w takim razie życzyć Rosjanom, by obecnie się bogacili, bo gdy będą syci, to zacznie im brakować czegoś więcej niż tylko zapewnienia godnego bytu, co pociągnie za sobą nowy wybuch wolnościowych dążeń.

W ramach trzeciego panelu zaproszeni goście: Konstantyn Winokurow (dyrektor filii Instytutu Gorszenina w Charkowie), Jan Andrzej Dąbrowski (Kolegium Europy Wschodniej) oraz Maryanna Prokop (politolog, doktorantka na Wydziale Politologii i Studiów Międzynarodowych) próbowali skonstruować powyborcze scenariusze dla Ukrainy.

Prowadząca, Maria Przełomiec, wskazała, iż w ostatnich wyborach żadna z partii nie uzyskała wyniku, który pozwoliłby jej na samodzielne rządy. Jednak nawet połączone siły partii opozycyjnych nie zdołają osiągnąć większości parlamentarnej. Na to nakładają się liczne problemy - nie jest znany termin kolejnego szczytu Unia Europejska-Ukraina (co oddala perspektywę podpisania paktu stowarzyszeniowego), w gospodarce widać początek recesji, Ukraina zbliża się do Wschodu poprzez wejście do unii celnej z Rosją, Białorusią i Kazachstanem, a do tego trwają prace nad nową ustawą referendalną, która sprawi, że za pomocą referendum będzie można zmienić nawet konstytucję. Pytanie, które otworzyło dyskusję, brzmiało - co może z tego wyniknąć?

Zdaniem K. Winokurowa opozycja ma dzisiaj wiele wewnętrznych problemów, na czele z tym, kto ma jej przewodzić. Jednak należy wskazać, iż fakt, że w ostatnich wyborach aż 70\% wyborców było przeciwko obecnej władzy, jest sukcesem.

M. Prokop zwróciła uwagę, że wyniki wyborów pokazują, że Ukraina wciąż balansuje pomiędzy Wschodem a Zachodem. Tak też zresztą postrzega ją Zachód - jako podzieloną na strefy: pomarańczową i niebieską. Dry- 
fowanie Ukrainy pomiędzy strukturami Wschodu i Zachodu pokazuje, że jest to system hybrydowy, bez jednego, konsekwentnie realizowanego pomysłu na przyszłość. Na dzień dzisiejszy nie ma wyznaczonego jednoznacznego kierunku, w którym zmierzać ma Ukraina, co samym Ukraińcom nie przeszkadza, ponieważ daje to możliwość politycznego balansowania (Rosja to bowiem tani gaz, a Unia - możliwość rozwoju).

A. Dąbrowski wskazał na różne cele polskiej i europejskiej sceny politycznej w polityce wschodniej. W tej sytuacji na pytanie „co robić?” należy odpowiedzieć - realizować polską rację stanu, czyli utrzymywać stałe relacje z Ukrainą oparte na prawdzie. Dążyć także należy do zmiany podejścia europejskiego - sytuacja Ukrainy zmieni się bowiem diametralnie, gdy kraj ten dostanie jasną perspektywę na członkostwo w strukturach unijnych. Trudno bowiem obecnie oczekiwać, że Ukraińcy będą czekać pod „zamkniętymi drzwiami”. W obecnej sytuacji Ukraina po prostu jest zmuszona do lawirowania pomiędzy Rosją a Europą. Próba bojkotu władz Ukrainy jest pozbawiona sensu, prowadzi donikąd i przede wszystkim nie daje szans na poprawę relacji. Trzeba jednak cały czas naciskać na władze Ukrainy, by dokonywały demokratyzacji kolejnych aspektów życia społecznego.

W związku z tymi uwagami powstało pytanie o to, czego Ukraina potrzebuje od Unii Europejskiej. M. Prokop wskazała, że głównym problemem Ukrainy jest kwestia ekonomii. Bez zagwarantowania podstawowych potrzeb życiowych ludzie nie będą myśleć o swoich prawach i swobodach. $\mathrm{K}$. Winokurow liczy na mocniejsze reakcje Europy na niedemokratyczne gesty ze strony ukraińskiej władzy. Dla A. Dąbrowskiego mówienie o polityce wschodniej zastąpiło rzeczywistą politykę wschodnią. Nikt nie chce powiedzieć wprost, że Partnerstwo Wschodnie jest porażką i należy je porzucić na rzecz nowej, lepszej strategii. Przy tym należy pamiętać, że skuteczna polityka zaczyna się od wizji, a tej w obecnych elitach Zachodu brak.

Dyskusja zakończyła się próbami ustalenia przyszłych wydarzeń na Ukrainie. Ostatnie wybory parlamentarne były bowiem tylko próbą sił przed wyborami prezydenckimi w 2015 r. M. Przełomiec zadała więc pytanie, jakie są szanse na to, że opozycja wyłoni jednego, silnego kandydata na prezydenta.

W. Kliczko w krótkim czasie potrafił zagwarantować fenomenalny wynik wyborczy, więc przez pozostałe dwa lata ma szansę ten sukces powiększyć stwierdziła M. Prokop. Przy tym były bokser wie, jak wyglądają zachodnie 
rozwiązania. Jednak póki co na niższym szczeblu jego partii brak jest ludzi kompetentnych i to zdaniem politolog należy zmienić. W ocenie K. Winokurowa nie sposób obecnie określić, czy w wyborach prezydenckich opozycja wystawi jednego kandydata. Należy nadto pamiętać, że w polityce musi być dużo treści, a tego na razie u W. Kliczki nie widać. Postać boksera jest dla A. Dąbrowskiego jedną wielką niewiadomą. Nikt na razie bowiem nie jest w stanie określić, jak rozwinie się on jako polityk.

Na zakończenie miał miejsce publiczny pokaz filmu Białoruskie marzenie (reż. Ekaterina Kibalchich), który opowiada o wydarzeniach na Białorusi od czasu wyborów prezydenckich w $2010 \mathrm{r}$.

Maciej Tarasek Uniwersytet Śląski 